\title{
Die verband tussen ekklesiologie en kerkreg: 'n Hervormde perspektief
}

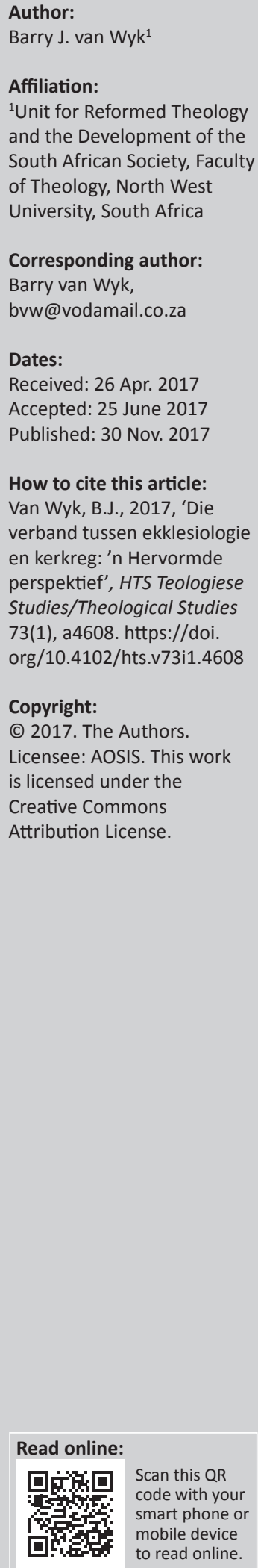

\begin{abstract}
This article discusses the meaning of ecclesiology and church polity as such, in relation to each other, but also in connection to church order which lies in the elongation of both. From a reformed perspective, it is indicated that the ecclesiology of the Netherdutch Reformed Church over the last fifty to hundred years, centred round the viewpoint of the Church as a volkskerk, in conjunction with the church orderly, of the Kerkwet till 1997. The author is of the opinion that the above-mentioned viewpoint limited the church to be a true church of the Word.
\end{abstract}

\section{Inleidend}

Daar is geen twyfel en geen debat oor die vraag of die Nederduitsch Hervormde Kerk van Afrika 'n kerk is wat die sestiende-eeuse Reformasie as oorsprong het, en derhalwe steeds erns maak met een van die mees wesenlike erfstukke uit dié tradisie, naamlik sola scriptura. Daarom spreek dit vanself dat ekklesiologie prinsipieel 'n leer oor die kerk is wat op die Bybel as Woord van God gegrond is. Dit verbaas nie dat die Bybel derhalwe ook as die primêre bron vir die kerkreg beskou word (Calvyn 1992:1317; Coertzen 1991:121-123; Noordmans 1984:392; Pont 1981:190) en die resultate van die erns maak van die Woord, deur die kerkreg in kerkordes van kerke afleesbaar is. Dit het tot gevolg dat Skrif, ekklesiologie en kerkreg, waarby ook kerkorde gevoeg kan word, in mekaar se verlenging lê. Die meedoënlose, hardnekkige en voortdurende terugkeer tot die Woord is die Bybelse erflating waarheen 'n kerk van die Woord telkens móét terugkeer om reg te laat geskied aan semper reformanda, die eis om aan kritiese selfondersoek uiting te gee en nie te stol binne onkritiese selftevredenheid nie.

Meegaande bydrae wil aandui hoe die Hervormde Kerk oor jare omgegaan het met ekklesiologie en kerkreg, gesien binne die Bybels-teologiese vertrekpunt en eie tradisie wat uit die Reformasie spruit. Eenvoudig gestel is 'n kerk uit Reformatoriese tradisie niks anders nie as kerk van die Woord. Die vraag ontstaan dus hoedanig die ekklesiologie van die Hervormde Kerk daar uitgesien, of moes uitgesien het, en hoe dit kerkregtelik in kerkordes (kerkwette) neerslag gevind het.

\section{'n Nadere presisering van ekklesiologie en kerkreg Van ekklesiologie}

Ekklesiologie was nie aanvanklik deel van die sistematiese teologie nie en wat die Reformasie betref was dit eers Philippus Melanchton wat in sy latere uitgawe van sy Loci (1535) aandag gee aan die ekklesiologie deur 'n gedeelte in te voeg bekend as De Ecclesia (Kärkkäinen 2002:11; Pannenberg 1998:21-27). Nadenke oor die ekklesiologie het daaruit gevolg wat by Calvyn (1992:Deel 4), Barth (kyk KD II/2, IV /1, 1970:9, 15), Moltmann (1975) en Küng (1986) gevind word onder andere, en in die twintigste eeu besondere aandag geniet (vgl. Van den Brink \& Van der Kooi 2012:518). Dat die ekklesiologie in die brandpunt staan word bevestig deur die hedendaagse debat wat oor die missionale gerigtheid van die kerk gaan:

A missional church is a church that defines itself, and organizes its life around its real purpose as an agent
of God's mission to the world. In other words, the church's true and authentic organizing principle is
mission ... The mission of God flows directly through every believer and every community of faith that
adheres to Jesus. (Hirsch \& Catchim 2012:409-410)

Dié benadering het veral ter sprake gekom na 'n groep missioloë se publikasie in Noord Amerika in 1988 'and became a cliché that today means everything or nothing' (Hirsch \& Catchim 2012:409-410; vgl. Petersen 2013:7).

Dit is egter opvallend dat die missionale debat ook 'n Skriftuurlike debat is soos in die volgende uitspraak gestel word: 
To the question of authority the first answer is, as we have seen, 'in the name of Jesus'. It is by this name that Paul introduces himself in his letters: he is a messenger sent by Jesus, called and sent by one greater than himself. There is no authority beyond that to which he can appeal. (Newbigin 1995:257)

Miskien hang dit saam met die betekenis-onderskeid wat geheg word aan credo in Spiritum sanctum en credo ecclesiam (eie beklemtoning). Die kerk bely Vader, Seun en Gees as geloofsinhoud, terwyl die kerk nie in sigself glo nie maar die kerk hoogstens onderwerp (Gegenstand) van geloof is (Beker \& Hasselaar 1990:226; vgl. McGrath 2007:404). Dit beteken dat 'n ekklesiologiese uitgangspunt altyd 'n Skriftuurlike argument is (moet wees) soos inderdaad in die volgende uitspraak gestel word: 'Die Ekklesiologie ist, wie bisher der Augenschein zeigen konnte, in ihrem Kern Christologie' (Weber 1962:575; vgl.Van der Walt 1976:15).

Ekklesiologie het 'n Skriftuurlike basis en 'n debat oor die ekklesiologie kan nie anders as om die Skrif as Woord van God te raadpleeg met die oog op die goeie gang van die kerk in die hedendaagse praktyk nie. Dit is derhalwe belangrik om ook in die huidige kerklik-ekklesiologiese debat waar missionaal sterk beklemtoon word as 'n alles of niks uitgangspunt soos gestel is, die Christologiese fundering ernstig te neem. In dié verband bly die uitgangspunte van Calvyn, Barth, Moltmann en Küng bruikbaar ook vir hedendaagse kerk-wees aangesien hulle eintlik met 'n Christologiese-ekklesiologie werk wat 'n besondere stimulans aan missionaal verleen.

Diversiteit in veral die Nuwe Testament oor die kerk beteken dat verskillende fasette en beelde van kerk-wees gevind word. Die feit word deur Kärkkäinen (2002) en Pelser (1995) aangedui en deur Käsemann (1968:262) se uitspraak 'Das Neue Testament schenkt uns keine ecclesiologia perennis, bietetunsjedochekklesiologische Grundtypen' bevestig (vgl. Minnear 1960). McGrath (2007:408) wys daarop dat die merktekens van die kerk soos aangedui in die Apostolicum, naamlik een heilig, katoliek en apostolies van belang geag word vir die ekklesiologiese debat sedert die vierde eeu.

Daarom val dit nie vreemd op nie dat die Nederduitsch Hervormde Kerk van Afrika ook oor die ekklesiologie nagedink het en oor jare 'n bepaalde ekklesiologie nageleef het in die lig van sy eie standpunt om Kerk van die Woord te wees.

\section{Van Kerkreg}

Breed gesien sou gestel kan word dat die Kerkreg die teologiese vakgebied is wat besig bly met die bestudering van die kerklike reg as sodanig soos geformuleer in die eie kerklike orde en uit die aard van die saak ook kerkordes van die verlede in die eie, asook ander kerklike tradisies. Die vertrekpunte in die vakgebied is belangrik en indien van die standpunt uitgegaan word dat die kerk bloot 'n sosiaalmenslike vereniging is, sal ander insigte na vore kom as die kerkregtelike uitgangspunt wat die kerk sien as van God, waarvan Jesus Christus die Hoof is en die Gees as waarborg funksioneer van die erfdeel van gelowiges (Ef 1:14, 22-23; vgl. Heidelbergse Kategismus, vraag en antwoord 54, Nederduitsch Hervormde Kerk van Afrika [NHKA] 2012:21).

Kerkreg besin dus voortdurend oor sy bronne, sy norme waarvolgens en metode aan die hand waarvan gedink en gehandel moet word. Die feit dat die Skrif as Woord van God en norm vir die kerklike reg as die primêre bron van die kerkreg beskou word, loop daarop uit dat die arbeid van die kerkreg soos geformuleer in die kerkorde, nooit 'n afgehandelde saak is nie. Dit veral gesien in die lig van die feit dat die Kerk 'n belydende kerk is en die vraag na Skriftuurlike gronde altyd aan die orde is en dus onafgehandel bly.

In die lig daarvan kan die kerklike reg tipeer word as dié deel van die teologiese wetenskap wat besig bly met die iu sconstitutum [die reg soos dit daar uitsien] en die ius constituendum [die reg soos dit behoort te wees] (Bouwman 1985:2; Coertzen 1991:158). Vanweë die bronmatige en kontekstuele vlak waar die kerkreg funksioneer is die kerkreg eiesoortig (ius sui generis) en nie gelyk aan die reg wat in die burgerlike wetgewing (ius circa sacra) beoefen word nie: 'Principieel is het kerkrecht eene theologische wetenskap, omdat het tot inhoud heeft het recht, dat in de kerk geldt en gelden moet volgens de H. Schrift' (Bouwman 1985:13).

Anders gestel: vanweë die Skriftuurlike bepaaldheid van die kerkreg kom die vraag na vore of kerkreg ius divinum (goddelike reg) of ius humanum (menslike reg) is. Heckel (1964:659) het die belang van die regte verstaan van iusdivinum beklemtoon met sy uitspraak:

'Von der Antwort wird die Stellung der Kirche zum Recht, insbesondere ihre Auffassung des Kirchenrechts sowie ihr rechtliches Handeln entscheidend bestimmt'. Dit is gepas om 'n kerkorde nie sonder meer as ius divinum te tipeer nie want die moment wanneer op grond van die Skrif ' $n$ bepaalde formulering soos in 'n kerkorde gemaak is, is dit ius humanum wat as sodanig hanteer moet word en die tekens van menslike onvermoë reflekteer (Van 't Spijker 1972:6; vgl. Barth 1964:808).

Goddelijk recht is recht van Christus. Christus oefent dit recht uit door zijn Geest in de gemeente. Goddelijk recht is dus geestelijk gemeenterecht, waarbij de opbouw van de gemeente het doel is (Van 't Spijker 1972:12; vgl. Coertzen 1991:52).

Barth (1964:768) beklemtoon die Christologies-ekklesiologiese uitgangspunt van die kerkreg wanneer hy sê: 'Es würde nicht ratsam sein, die Begründung des Kirchenrechts von einem anderen als eben dem christologisch-ekklesiologischen Begriff der Gemeinde her unternehmen zu wollen'. Die Christelike gemeente is die menslike gemeenskap waarin Christus as hoop, voorrang geniet en die menslike en menslik handelende gemeenskap van die heiliges, sy liggaam in Hom sekondêr tot gestalte kom, 'dann sagt man schon, indem man "Gemeinde» sagt, auch Ordnung und Recht' (Barth 1964:770).

Uit nadere geledere is gestel dat kerkreg 'die reëls [is] wat deur ampsdraers uit die beginsels, gegee in die Woord van God, 
gevorm is vir die gedrag in die gemeenskap van die gelowiges' (Van der Linde 1965:32). Of: '[g]egewe hierdie werklikhede sou kerkreg omskryf kon word as die teologiese wetenskap wat die organisasie van die kerk in sy Skriftuurlike en historiese gestalte bestudeer' (Coertzen 1991:166). Wanneer Bouwman (1985:29) sê die bron van die kerkreg is gelyk aan die wil van die Koning van die kerk, trek dit 'n duidelike riglyn met betrekking tot die bron(ne) van die kerkreg. 'Alleen die kerkinrichting is de ware, die uit Gods Woord geput is en met de orde van de apostolische kerk in overeenstemming is' (vgl. Bronkhorst 1947:276-277; Coertzen 1991:120-124; Pont 1981:7; Van ‘t Spijker 1990:327-329).

Beklemtoning van die Skrif as primêre bron vir die kerkorde impliseer nie 'n pasklaar kerkorde nie, maar beteken ook nie dat 'n kerkorde as resultaat van Skriftuurlike ondersoek, nie as 'n Skriftuurlike kerkorde tipeer kan word nie. Daarom het Van Ruler (1952:90) gestel dat 'n kerkorde ius humanum is, maar die harde kern van die ius divinum verwoord! Dit gaan in 'n kerkorde oor ekklesiologie wat berus op bepaalde keuses wat bepalend was of is tydens die aanvaarding van die kerkorde (Koffeman 2009:11).

Die Skrif as primêre bron vir die kerkreg en kerkorde waaroor daar in die Reformatoriese tradisie nie twyfel oor bestaan nie, lewer 'n kritieke bydrae vir die formulering van 'n kerkorde. Die resultate waartoe die ekklesiologie gekom het kan kerkordelik as ' $n$ kerkbegrip tipeer word en werk bepalend mee aan 'n kerkorde soos geformuleer op 'n gegewe moment.

Die volgende mening is bruikbaar in diens van die waardering van wat kerkreg en kerkorde veronderstel is om te wees:

De kerkorde is niet in de eerste plaats een juridische document, maar geeft regelingen voor het leven en werken van de kerk om het mogelijk te maken aan haar roeping te beantwoorden. De kerkorde is daarom (ook) sterk theologisch bepaald. (Van den Heuvel 2004:72)

In die verband is die Dingemans (1988:207) uitspraak dat 'n kerkorde in regsreëls vertaalde ekklesiologie is, steeds bruikbaar. Van de Beek (2012) sê:

Een kerkorde is immers iets anders dan het reglement van een vereniging. Een kerkorde is expressie van wat de kerk is: een door Christus bijeenvergaarde en bijeengehouden werkelijkheid. ... De orde representeert de orde van Christus in de conditie van de aardse bedeling: niet in de gestalte van de heerlijkheid, maar in de gestalte van het kruis. (bl. 224)

Ten diepste het die kerkreg dus 'n geestelike doel: 'het wil de kerk die bewerktuiging geven waardoor zij waarlijk als Kerk-metde-grote-K, als van Christus afhankelijke geloofsgemeenschap, kan functioneren'(Bakker 1988:14) wat mutatis mutandis ook vir 'n kerkorde geld.

\section{Ekklesiologie en kerkreg (kerkorde)}

Koffeman (2009:16-17; vgl. Dingemans 1988:220) wys in dié verband op twee geblokkeerde weë wat voorkom moet word. Die een is om tevrede te wees soos dit nou eenmaal tot stand gekom het en te volstaan met 'n minimum kerkregtelike reëlings wat daarop uitloop dat die kerk van die teologie losgemaak word en as 'n instituut beleef word.

Die tweede geblokkeerde weg is om kerkreg uitsluitlik as die geykte teologie van 'n bepaalde gemeenskap uit die verlede te sien wat as 'n kerk-juridiese konfessionalisme bestempel kan word. Dit kom daarop neer dat bepaalde kerkordelike maatreëls uit die verlede sonder meer aanvaar word sonder die nodige krities-teologiese besinning. Dat in 'n bepaalde kerkregtelike tradisie verkeer word en daarin geleef word is bruikbaar maar kan nie gebruik word om die kritiesteologiese eiegoed te blokkeer nie.

As voorbeeld van laasgenoemde kan nie kritiekloos en ongekwalifiseerd net na Calvyn (of Dordt 1618-19) verwys word as 'n belangrike rolspeler in die Reformatorieskerkregtelike tradisie nie, sodoende word die situasie in sy verlede sonder mee rnormatief gemaak vir die hede. Die kritiese uitspraak van Koffeman is bruikbaar wanneer hy daarop wys dat kerkreg veranker is in ekklesiologie, maar dat ook in gedagte gehou moet word dat nie alle kerkordelike formuleringe met dieselfde gewig vanuit die ekklesiologie afgelei word nie. Haitjema (1951:142) het dit as die relatiewe en absolute van 'n kerkorde bestempel.

In die lig van die noue relasie tussen ekklesiologie en (kerkreg) kerkorde sou 'n afwesigheid van volgehoue kritieskerkregtelike denke daarop neerkom dat kerkordelike maatreëls soos dit eenmaal tot stand gekom het finaal is, wat krities beskou 'n bepaalde iusdivinum impliseer gesien teen die noue verbinding tussen Skrif en Kerkorde.

\section{Die Hervormd-kerklike verlede oor ekklesiologie en kerkreg}

Oberholzer (1999:449) het met die draai van die eeu die opmerking gemaak dat die Kerk gekonfronteer word met die mislukking van so byna alles waarmee die Kerk besig was. Die groei van die Kerk het negatief geword, ekonomies worstel die Kerk om voort te bestaan en krities stel hy dat sy teologiese voorraad in baie opsigte onbruikbaar geraak het.

Die ekklesiologiese vormgewing van die Hervormde Kerk oor die laaste vyftig, ja selfs honderd jaar kan sekerlik nie losgemaak word van die situasie waarin die Kerk hom bevind het nie. Oberholzer (1999:450) vat dit kort en bondig saam en tipeer die pad waarop die Kerk hom bevind het as 'n gebonde pad. Dit was gekenmerk deur 'n mislukte kerkvereniging (1885), 'n fisiese stryd om oorlewing na die drie-jarige oorlog (1899-1902), gevolg deur 'n tydperk van geweldige armoede wat lidmate in minder belangrike posisies van die arbeidsmag van die samelewing laat beland het. Die afwesigheid van 'n geleerdheidstradisie in 'n Kerk met arm lidmate het daartoe bygedra dat die Kerk op die sosiale helling te staan gekom het, saam met sy lidmate wat boonop 'n stryd gevoer het om politieke oorlewing. Die omstandighede waarbinne die Kerk kerk moes wees, het 'n bepaalde invloed uitgeoefen wat sekerlik as versagtende 
omstandighede gesien kan word, maar tog nie noodwendig ten goede was vir die beeld wat van buite af oor die teologiese diepgang van die Kerk gevorm is nie.

Van Wyk (1999:270-274) identifiseer bepaalde redes wat hy meen die Kerk verlam het om met sy ekklesiologiese tradisie voort te gaan, soos die Kerk se antropologiese onderbou en geskiedenisvisie, gekomplimenteer deur 'n sosiale etiek wat sy begronding in ' $n$ bepaalde vorm van die teokrasie gevind het. Dit het meegebring dat die ekklesiologie van die Kerk met sosiaal-etiese sake geworstel het vanweë die voortvloeiende visie op gemeenskap en staat.

Dit sou ook beweer kon word dat wanneer oorkoepelend na die ekklesiologie van die Hervormde Kerk gekyk word, veral twee uitgangspunte na vore kom. Die een is dat die Hervormde Kerk homself as ' $n$ volkskerk gesien het en daarmee saam in sy Kerkorde (kerkwet) ${ }^{1}$ tot 1997 vasgehou het aan wat bekend gestaan het as Artikel III. Artikel III was hoe min sommige dit sal wil toegee, 'n rasmatige bepaling wat in die Kerkorde opgeneem is [sic], met 'n veel langer aanloop en hou verband met die histories-polities en maatskaplike situasie waarin die lidmate van die Kerk hulle bevind het, soos verwoord in die redes vir die Groot Trek (1836), naamlik weerstand teen die Engelse besetting van die Kaap en die gevolglike beleid van gelykstelling tussen alle rasse (Duvenage 1987:209-211; Pont [1969]:213; Storm 1989:14-19). Dit was waarskynlik tydens die Algemene Kerkvergadering van Februarie 1888 waar die Hervormde Kerk, na die mislukte kerkvereniging van 1885, kerkordelik as volkskerk beslag gekry het, veral onder invloed van Ds M.J. Goddefroy (Pont [1969]:211-217; vgl. Koekemoer 1987:18).

Rasseverskille en die spanning wat daarmee gepaard gaan, het bly vassteek en speel 'n rol in die verdere kerkordelike gang. In die Kerkwet, soos vasgestel deur die Algemene Kerkvergadering van 1937, word die verhouding tussen rasse soos volg verwoord: 'Die Kerk gaan uit van die beginsel van onderskeid tussen blankes en nie-blankes en erken geen gelykstelling tussen blank en nie-blank nie' (Artikel 5). Lidmaatskap word beperk tot blanke persone wat in die Kerk gedoop is, belydenis afgelê het of van ander kerke afkomstig is (Artikel 2) (NHKA 1937:5-6). Die beperking van lidmaatskap tot blankes en die geen gelykstelling uitgangspunt tussen blankes en kleurlinge, kom reeds in die Kerkwet van 1904 voor (NHKA 1904:3). Dit is die naloop van die Algemene Kerkvergadering van 1888 waar die Kerk as gevolg van die feit dat kerk en staat nie meer so nou verbonde was nie, maatreëls geformuleer het om homself te beskerm. Vir die Kerk, na die mislukte kerkvereniging, is die Algemene Kerkvergadering van 1888 waarskynlik die historiese beginpunt van volkskerk en Artikel III soos dit later teruggevind word (Pont 1969:213).

Die Kerk het in die jare vyftig 'n nuwe Kerkwet in gebruik geneem wat geskoei was op die nuwe Kerkorde van die
Nederlandse Hervormde Kerk wat op 01 Mei 1951 in gebruik geneem is (Bronkhorst 1976:132; vgl. Van Wyk 1991:171-173). In die Kerkwet van 1951 het die bekende Artikel III verskyn en het die Kerk sy selfverstaan as volkskerk soos volg geformuleer:

Die Kerk bewus van die gevare wat vermenging van blank en nie-blank vir altwee groepe inhou, wil geen gelykstelling in sy midde toelaat nie, maar beoog die stigting van eie volkskerke onder verskillende volksgroepe, in die oortuiging dat aldus die bevel van die Here - 'Maak dissipels van al die nasies' Matteus 28:19, die beste tot sy reg sal kom en dat die eenheid in Christus deur so ' $n$ werkverdeling nie geskaad sal word nie. Tot die Nederduitsch Hervormde Kerk van Afrika behoort daarom slegs blanke persone. (NHKA 1957:1)

Artikel III verskyn steeds in die Kerkwet van 1993 (NHKA 1992) wat tydens die drie en sestigste Algemene Kerkvergadering (1992) vasgestel is waarin in vergelyking met die 1951 formulering, bygevoeg is dat lidmate in die Kerk deur die Doop opgeneem is, belydenis van geloof afgelê het, uit ander kerke opgeneem is en kinders van lidmate van die Kerk is. Die rasmatige bepaling van blankheid is vooraan geplaas waarin gestel word dat tot 'die gemeentes en derhalwe tot die Nederduitsch Hervormde Kerk van Afrika, behoort blanke persone' soos vermeld in die gestelde vier moontlikhede (eie beklemtoning) (NHKA 1993:1). Artikel III sou bly staan tot 1997 (NHKA 1997:59), terwyl volkskerk eers verwyder is tydens die een en sewentigste Algemene Kerkvergadering van 2016.

Die druk op die Kerk met betrekking tot sy ekklesiologie het met verloop van tyd toegeneem en die ingrypende politieke verandering van 1994 het die handhawing van 'n rasmatige bepaling in die Kerkorde onhoudbaar gemaak. Behalwe vir die politieke veranderinge was dit problematies om na Matteus 28:19 te verwys as Bybels-ekklesiologiese motivering om kerk te wees waar lidmaatskap óók op grond van ras bepaal word. Sonder om op volledigheid aanspraak te maak word die Kerk se ongemak met veral Artikel III verraai deur intense debatte tydens Algemene Kerkvergaderings, maar ook deur die aantal studiestukke deur individue en kommissies wat die resultaat is van jarelange debat in die verband soos deur Van Wyk (1985:1) aangedui word. Die Kerk was redelik oortuig van sy ekklesiologiese model beoordeel vanuit die Herderlike skrywe van 1973 waar onder andere gestel word:

Die kerk wil weer eens beklemtoon dat dit vir hom in die onderhawige saak nie slegs om 'n tussentydse reëling gaan nie, maar om 'n blywende en onveranderlike beginsel wat Skriftuurlik gefundeer is . (Van Wyk 1978:261, [outeur se eie kursivering])

Die oortuiging van die Kerk blyk verder onder andere uit die besluit van die Algemene Kerkvergadering van 1961 dat uit 'geslagtelange ervaring met die kleursituasie in Afrika' vermenging, 'veral op die terrein van die kerk, onberekenbare skade doen aan die verkondiging van die evangelie van Gods koninkryk' (Van Wyk 1978:70).

Wanneer na die inhoudsopgawe van die bundel Stemme uit die verlede (Van Wyk 1978) gekyk word, handel die eerste 
gedeelte oor die rassekwessie in Suid-Afrika (27), tweedens kom Artikel III ter sprake (4), gevolg deur kerk en sending (11) en die laaste gedeelte bevat bydraes oor amptelike besluite en uitsprake van die Kerk oor volkereverhoudings (12). Die getal tussen hakies na elke onderwerp dui die aantal bydraes van verskillende skrywers aan wat in dié bundel opgeneem is. Ongeag die feit dat Artikel III telkens met groot meerderheid herbevestig is tydens Algemene Kerkvergaderings, het die debat nie sonder spanning en meningsverskil verloop nie.

Van Eck (1995:838) verwys na die sieninge van Greyvenstein en Geyser onder andere, waaruit blyk dat laasgenoemde veral sedert 1960 direkte kritiek teen volkskerk en Artikel III gelewer het. Die groep teoloë wat weerstand gebied het was egter ver in die minderheid waarvan sommige soos proff. A. Van Selms en A. S. Geyser (vgl. Dreyer 2016; Van Aarde et al. 2014; Van Wyk 1992:515-516), die Kerk verlaat het. Die publikasie Vertraagde aksie (Geyser et al. 1960) is 'n voorbeeld van die kritiek wat in die eie Kerk, asook in susterkerke ter sprake gekom het.

In die lig van die Kerk as volkskerk en daarmee saam die handhawing van Artikel III het die Kerk probeer erns maak met sy sendingopdrag. Die eerste sending kommissie is reeds in 1928 gekies met dr H.C.M. Fourie as voorsitter en ds. S. Vermooten as sekretaris (Van Wyk 1978:72).

Die Kerk het egter oortuig gebly dat ' $n$ beleid van gelyke en afsonderlike geleenthede vir elke volk en volksgroep steeds die beste is vir die situasie in Suid-Afrika. Die Kerk het in ' $n$ getuienis van die Kommissie (1977) beklemtoon dat daar geen ruimte is vir optrede wat ' $n$ medemens leed berokken nie, die gelykheid van alle mense voor God aanvaar en meerderwaardigheid van die een teenoor die ander verwerp. Die Kerk het verder die ontugwet en die verbod op gemengde huwelike gesien as noodsaaklike maatreëls vir die beskerming van die identiteite van die onderskeie volkere en volksgroepe en het daarom ook gesamentlike aanbidding nie as 'n verstandige wyse beskou om die evangelie aan alle mense te verkondig nie (Van Wyk 1978:278-279).

Die verdediging van die volkskerk, soos opnuut verwoord in die Herderlike skrywe van die Kommissie van die Algemene Kerkvergadering (1990), dui op die spanning wat die handhawing van dié standpunt geskep en daarop uitgeloop het dat die Kerk die siening voortdurend moes verdedig en uitlê (NHKA 1990:11).

Tog het die Kerk homself as volkskerk ernstig gepropageer soos blyk, naas die kerkordelike formulering tot 2016, ook verwoord is in ten minste twee publikasies wat onderskeidelik in 1973 en 1989 verskyn het (Botha 1973; 1989). Ten spyte van jarelange verdediging en uitleg en al die goeie bedoelinge wat die Kerk gehad het met volkskerk en Artikel III, in die lig van die Kerk se volgehoue belydenis dat die Woord bepalend is, het die Kerk nie daarin geslaag om in ekumeniese verband in Suid-Afrika, maar ook in die buiteland, kritici te oortuig nie. So asof die onafwendbare besef is, word gestel dat indien dit onmoontlik word om 'n eksklusiewe Blanke kerk te bly, moet sy (Blanke) lidmate daartoe gelei word om te besef dat dit nie die einde van die kerk sal beteken nie, omdat die wese van die Nederduitsch Hervormde Kerk nié daardeur bepaal word dat hy 'n eksklusiewe Blanke kerk is nie, maar kerk van die Woord (eie beklemtoning) (NHKA 1985:71).

Dalk is die reaksie (vgl. Pont 2011) wat gespruit het in die verklaring oor apartheid wat tydens die nege en sestigste Algemene Kerkvergadering (NHKA 2010) aanvaar is en die kerklike afskeiding wat daarop gevolg het, aanduiding waarom die Kerk ontslae moes raak van apartheid en in die verlenging daarvan, ook volkskerk. Dit is opvallend dat die Kerk skuld bely het oor apartheid, maar slegs oor die wandade van apartheid wat mense ('selfs deur lidmate van die kerk') gepleeg het en nie oor apartheid as sodanig nie (NHKA 2001:171-174). Tydens die sewentigste Algemene Kerkvergadering het 'n Beskrywingspunt ontvang van die gemeente Pretoria gedien as poging om die besluit van die vorige Algemene Kerkvergadering te korrigeer, wat nie aanvaar is nie (NHKA 2013:44).

In verband met die teologiese eienaardigheid van die teologie van die Kerk wys Oberholzer (1993) op lidmate en ampsdraers wat die gesag van die Kerk en teologie agter hulle eie politieke opvattings wil inspan, die gevaar dat die kerk uit reaksie sy nugterheid mag verloor, die politisering van Artikel III of die beskouing dat hy enigsins 'n fundamentele funksie in die kerk vervul, wangebruik en misbruik van die Bybel (bl. 884).

In 'n meer resente weergawe van die dilemma waarin die Kerk oor jare beland het, word gestel dat 'die sinonieme tussen "Afrikaner", "volk" en "blank" wat hier gebruik word, vra dat die gedagte van 'n "volkskerk" eweseer as 'n "raskerk" verstaan sal word' (Wolff 2006:157).

Dit is derhalwe nie vergesog om te beweer dat die ekklesiologie wat in die Hervormde Kerk ter sprake gekom het, sterk bepaal is deur die Kerk as volkskerk, saam met Artikel III wat ook in die Kerk se apostolaat ingedra is ten minste tot 1997 (vgl. Kerkwet 1993: Bepaling 47; NHKA 1993:34).

Die siening oor die volkskerk soos verwoord in die Nederlandse Hervormde Kerk was tydens die Doleansie (1886) in die brandpunt wat deur iemand soos Kuyper (1837-1920) onder kritiek geplaas is teenoor Hoedemaker (1839-1910) wat die Nederlandse Hervormde Kerk as volkskerk verdedig het. Die Nederlandse situasie met 'n homogene bevolking was heel anders as in Suid-Afrika met sy volkere verskeidenheid en die kritiese vraag kan gestel word of, bewus of onbewus, die volkskerk siening nie handig te pas gekom het nie in diens van afsonderlikheid, teen die agtergrond van die politieke stelsel van apartheid, of afsonderlike ontwikkeling.

Van de Beek (1992) vat die essensie van wat volkskerk in Nederland bedoel was om te wees, (vgl. Bremmer 1973; Woelderink 1951) soos volg saam: 
Het grote visioen is dan ook 'een gedoopte nasie'.... Integendeel, het gaat om het leven uit de doop. 'Leer Nederland zijn doop verstaan en land en volk zijn gered'. In dezezinligt de kerngedachte van de volkskerk-idee. ... Het gaat erom, dat mensen opgenomen worden in de lijn van het verbond, dat God met ons gesloten heeft. (bl. 78)

Die debat van die eie Kerk het dit ook so gesien, naamlik dat die kerk van die Here en derhalwe ook die volkskerk, op twee grondpilare rus naamlik, verkiesing en genadeverbond. Die verbond vorm die grondslag van die kerk en die rede waarom gelowiges tot die kerk toetree omdat God hulle voor die skepping van die wêreld uitgekies het (Ef 1:4). 'Die grondslag van die kerk is vir die volkskerk die genadeverbond waardeur God uit vrye genade op grond van die kruisoffer van Christus Hom aan die mens verbind en die mens aan Hom' (Van Zyl 1989:90, 97).

Die Nederlandse Hervormde Kerk (Nederlandse Hervormde Kerk [NHK] 1969:11, 15) het ook die woord volkskerk geskrap maar genadeverbond behou (Kerkorde, Artikel II), selfs in Artikel VIII waar die formulering 'de kerstening van het volksleven in de zin der Reformatie' sterk daaraan herinner. Die Kerkorde van die Protestantse Kerk Nederland (PKN) (2004:10) praat van 'n 'Christus-belijdendegeloofsgemeenschap' wat gestuur en geroep is om die bediening van die versoening in die wêreld aan alle mense en aan alle volke te verkondig, want vanweë God se genade en kragtens sy verbond word gemeentes rondom Woord en sakrament vergader.

\section{Kritiese nabetragting}

Debat oor volkskerk en Artikel III, soos verwoord in die kerklike verlede, is 'n debat waarin steeds verskillende stemme gehoor word. Tydens die pas afgelope Algemene Kerkvergadering (NHKA 2016a:79-81) was daar woordvoerders wat van mening was dat volkskerk in die hersiene Kerkorde behou moes word. Dit het egter onhoudbaar geword veral as gevolg van die politieke verlede waarin die Kerk hom oor jare bevind het. Die voortdurende verklaring van die Kerk dat die Woord voorrang geniet en dat telkemale tot die Skrif teruggekeer word, het nie daarin geslaag om te voorkom dat volkskerk 'n politieke kleur gekry het nie en die Kerk waarskynlik as 'n laaste bastion beskou is teen die veranderinge wat sedert 1994 plaasgevind het. Die manier hoe anderskleuriges, wat dikwels uit groot peïteit vir die oorledene tydens begrafnisdienste behandel is, strek nie tot eer van die Kerk nie. Dié soort optrede verraai 'n mate van bevreesdheid en is op meerderwaardigheid gegrond. Die afskaffing van die ontugwet en die wet op gemengde huwelike wat die Kerk in die verlede belangrik geag het, toon aan dat die bedreigdheid misplaas was aangesien die vrees wat daarin gesien is, klaarblyklik nie bestaan nie, ten minste nie vir die Kerk nie. Debat oor die aangeleentheid was dikwels 'n politieke debat waar verdagmaking hoogty gevier het, veral as die ander party as 'n liberalis of kommunis tipeer kon word. Die vrees dat die Kerk se eredienste oorstroom sou word as volkskerk en Artikel III nie meer kerkregtelik gereglementeer is nie, was totaal misplaas. In 'n ongepubliseerde reaksie op die kerkskeuring tydens en na die nege en sestigste Algemene Kerkvergadering spreek Oberholzer (2010) hom soos volg uit:

$\mathrm{Al}$ die hoogdrawende uiteensettings oor wat die volkskerk is, word vals wanneer daar mense in die kerk is vir wie dit gewoon 'n rassebepaling is. En net so is Ordereël 4 vals wanneer daar mense in die kerk is wat dit verstaan as rassebepaling. (bl. 6)

Debat oor die aangeleentheid is in die verlede, maar ook in die hede nie altyd goed ontvang nie (vgl. Van Wyk 2013:4, 9). Dit is ironies dat die politieke situasie van die verlede waarteen ernstige kommer uitgespreek en kerkordelike maatreëls getref is, die Kerk na 1994 in 'n sekere sin gedwing het om op te hou om daaroor te bekommer en liewer te fokus op sy Bybels-teologiese erfenis.

Krities beskou is dit voor die hand liggend om wanneer 'n begrip soos volkskerk soveel spanning en misverstand veroorsaak, die woord te skrap. Die voortbestaan van die Hervormde Kerk hang nie af van die handhawing van volkskerk in die Kerkorde, al dan nie. Die goeie intensies wat die Kerk jare lank daarmee wou verwoord, soos om die evangelie aan alle mense te bring en binne die ruimte waarbinne die Kerk kerk moet wees die evangelie te verkondig, kan ongesteurd voortgaan want dit hang nie daarmee saam of die Kerk homself as 'n volkskerk tipeer nie. Die voortbestaan van die Kerk is nie afhanklik van 'n volkskerklike siening nie, want die Kerk sien homself as kerk van die Woord. Dit is ' $n$ besonder wesenlike uitgangspunt wat nie onderhandelbaar is nie en oor al die stryd en verlamming van die verlede die laaste woord nahou. Kerk van die Woord kan nie anders nie as om telkemale reg van vooraf te besin oor die draagkrag daarvan. Dit is eenvoudig. Wees maar net kerk van die Woord, sonder 'n nadere byvoeglike bepaling.

Uiteindelik het die Kerk dan die punt bereik waar Artikel III én volkskerk uit die kerkordelike bestel van die Hervormde Kerk geskrap is. Artikel III is verwyder toe die destydse Kerkwet (1993) deur die Kerkorde vervang is (Kerkorde 1997), en volkskerk met die aanvaarding van die hersiene Kerkorde tydens die een en sewentigste Algemene Kerkvergadering (vgl. NHKA 2016c).

Daarom is die Kerk eintlik daar waar Oberholzer (1999:449) gesê het die Kerk is, naamlik terug op die pad, waar hy onder andere gestel het dat die teologiese voorraad van die Kerk in baie opsigte onbruikbaar geraak het.

Die verbondsmatige inslag wat wesenlike teologiese sin aan kerk én volkskerk gegee het, is positief en dien om behoue te bly en spreek mee tot ekklesiologiese singewing. Barth (1959) spreek hom oor die verbondsmatige inslag van die kerk soos volg uit:

Dass er dieser Gott in der tat ist, das ist Gnade, das hat der Mensch nicht verdient, das kann ihm nur geschenkt sein' ... Es war im Anfang die Wahl des Vaters, diesen Bund mit dem 
Menschen darin wahr zu machen, dass er seinen Sohn für ihn dahingab, um selbst Mensch zu werden zum Vollzug seiner gnade. ... Er war die Wahl des Bundes Gottes mit dem Menschen. (bl. 108-109)

Dit hang nou saam met die klem wat in die Efesiërbrief kosmologies gesien word wanneer alles ondergeskik gestel is aan Jesus Christus en Hý derhalwe as Hoof bo alles, ook Hoof van die kerk wat Sy liggaam is, gegee is (Ef 1:22-23). Die oorsprong van die kerk lê buite die kerk, objektief van aard in die raad van God soos verwoord in Christus. Die feit dat die PKN die woord (volkskerk) onbruikbaar gevind het dien rigtinggewend ook vir die Hervormde Kerk en daarom was dit ekklesiologies bruikbaar om die begrip te skrap.

Ekklesiologie en kerkreg, wat daarvan? Beide het in gemeen met mekaar dat albei slegs vir die kerk bruikbaar is in die mate waarin Skriftuurliker elevansie blyk. Kerkreg het die verdere funksie dat die kerkorde wat op grond van die stand van die Kerkreg in 'n bepaalde kerk die lig sien, die omvange vertoon van die kerk se teologies-kerkregtelike voorraad. Nader besien, in die lig van die feit dat 'n kerkorde in regsreëls vertaalde ekklesiologie is, kom dit daarop neer dat beide, ekklesiologie en kerkreg (kerkorde), tekenend is van die manier hoe 'n kerk met die Woord omgegaan het. Die beklemtoning van Jesus Christus as Hoof van die kerk soos dit veral in die Efesiërbrief verwoord word, dui aan dat daar wesenlik nie sprake is van 'n ander of 'n nuwe ekklesiologie nie. Hoogstens sou dit daarop neerkom dat die nuut ontdekking van dié kritieke Bybelse uitspraak die kerk tot nuwe insigte bring en noop om van uitgediende teologiese voorraad ontslae te raak.

Die een en sewentigste Algemene Kerkvergadering (NHKA 2016a:30) het opnuut bevestig dat die uitdagings van ons tyd nie bepalend vir die wese van die kerk is nie, omdat die wese van die kerk deur die drie-enige God bepaal word. Die Kerk wil kerk van die Woord wees (eie beklemtoning). Verder is gestel dat die Hervormde Kerk homself sien as 'n sigbare gestalte van die een, heilige, algemene en apostoliese kerk. Daarom leef die Kerk in gemeenskap met God, met mekaar en met alle gelowiges wat bely dat Jesus Christus die enigste Here is. Dit is van betekenis dat die Kerk in die beskrywingspunt 'n nuwe interpretasie aan Matteus 28 gegee het naamlik, die bewussyn dat God die Kerk wil gebruik, dat die evangelie die Kerk in beweging bring en om die rede in gehoorsaamheid aan die opdrag van God, dit met ander deel en derhalwe missionaal leef. In die lig van die gestelde beskrywingspunt (Beskrywingspunt 1) wat tydens die een en sewentigste Algemene Kerkvergadering aanvaar is (NHKA 2016b:112), kan met instemming betuig word dat geen verdere byvoeglike naamwoord nodig is om die Kerk se standpunt duideliker te omlyn nie, daarom is dit nie 'n verlies dat die woord volkskerk nie meer in die Kerkorde wat tydens die vergadering vasgestel is, voorkom nie.

Dit is bruikbaar om in gedagte te hou dat missionaal voorafgegaan word deur wat genoem kan word 'n
Christologiese-ekklesiologie, wat 'n besonder wesenlike motivering gee aan 'n missionale ingesteldheid.

Ekklesiologie en kerkreg staan in noue verband met mekaar, aangesien in die omlyning van beide afsonderlik en in verband met mekaar, 'n Skriftuurlike debat ter sprake kom as uiting van die voor die hand liggende besig wees van 'n kerk van die Woord:

Ecclesiologie en kerkrecht staan in de praktijk in een spanningsveld, waarbij de 'harde' juridische structuur van het kerkrecht het voortdurend lijkt te winnen van de open ecclesiologievan de dogmatiek. (Dingemans 1988:210)

\section{Erkenning Mededingende belange}

Die outeur verklaar dat sy geen finansiële of persoonlike verbintenis het met enige party wat haar nadelig kon beïnvloed het in die skryf van hierdie artikel nie.

\section{Literatuurverwysings}

Bakker, W., [1988], 'Wat is kerkrecht?', in W. Van 't Spijker \& L.C. Van Drimmelen (red.), Inleiding tot de studie van het Kerkrecht, pp. 13-19, Kok, Kampen.

Barth, K., 1959, Kirchliche Dogmatik, II/2,EVZ, Zürich.

Barth, K., 1964, Kirchliche Dogmatik, IV/2,EVZ, Zürich.

Barth, K., 1970, Die KirchlicheDogmatik, Registerband, EVZ, Zürich.

Beker, E.J. \& Hasselaar, J.M., 1990, Wegen en kruispunten in de Dogmatiek, Deel 5, Kok, Kampen.

Botha, S.J., 1973, Die volkskerk, HAUM, Pretoria.

Botha, S.J., (red.), 1989, Belydende volkskerk, Kital, Pretoria.

Bouwman, H., 1985, Gereformeerd Kerkrecht, eerste deel, Goudriaan, Kampen.

Bremmer, R.H., 1973, 'Verbond en kerk: Enkele historische notities uit de Gereformeerde theologie', in Kerk en Theologie, 24 Jrg, pp. 30-42, Boekencentrum, 's-Gravenhage.

Bronkhorst, A.J., 1947, Schrift en Kerkorde, Zuid-Holland, Den Haag.

Bronkhorst, A.J., 1976, 'Kroniek: Op 1 Mei 1951 werd de Kerkorde der Ned. Hervormde Kerk ingevoerd', Kerk en Theologie 27(2), 126-149.

Calvyn, J., 1992, Institusie van die Christelike Godsdiens, Boek 4, CJBF, Potchefstroom.

Coertzen, P., 1991, Gepas en ordelik, ' $n$ Teologiese verantwoording van die orde vir en in die kerk, Raad vir Geesteswetenskaplike Navorsing, RGN-Uitgewers, Pretoria.

Dingemans, G.D.J., [1988], 'Kerkorde als ecclesiologische vormgeving', in W. Van 't Spijker \& L.C. Van Drimmelen (red.), Inleiding tot de studie van het Kerkrecht, pp. 207-220, Kok, Kampen.

Dreyer, W., 2016, 'Heretic or rebel? The heresy trial of Albert Geyser', HTS Teologiese Studies/Theological Studies 72(4), a3745. https://doi.org/10.4102/hts.v72i4.3745 Duvenage, G.D.J., 1987, Die Groot Trek, deel 2, Sigma, Pretoria.

Geyser, A.S., et al., (reds.), 1960, Vertraagde aksie: 'n Ekumeniese getuienis uit die Afrikaanssprekende Kerk, N. G. Kerkboekhandel, Pretoria.

Haitjema, T.L., 1951, Nederlands Hervormd Kerkrecht, Callenbach, Nijkerk.

Heckel, J., 1964, Das blinde undeutliche Wort 'Kirche', Ges. Aufsätze, Koln.

Hirsch, A. \& Catchim, T., 2012, The permanent revolution: Apostolic imagination and practice for the 21st century, Wiley, Kindle Edition, Jossey-Bass, San Francisco.

Jansen, J., 1952, Korte verklaring van die Kerkorde, Kok, Kampen.

Kärkkäinen, V., 2002, An introduction to eccelesiology, InterVarsityPress, Madison.

Käsemann, E., 1968, Exegetische Versucheund Besinnungen, Zweiter Band, Vandenhoek \& Ruprecht, Göttingen.

Koekemoer, J.H., 1987, 'Die volkskerkvoorstelling in die Kerkwet van die Nederduitsch Hervormde Kerk van Afrika', HTS 43(1 \& 2), 13-24.

Koffeman, L.J., 2009, Het goed recht van de kerk, Kok, Kampen.

Küng, H., 1986, Thechurch, SearchPress, Kent.

McGrath, A.E., 2007, Christian Theology, Blackwell, Malden.

Minnear, P.S., 1960, Images of the church in the New Testament, Westminster, Philadelphia, PA.

Moltmann, J., 1975, Kerk in het krachtveld van die Geest, bouwstenen voor een messiaanse ekklesiologie, Ambo, Baarn. 
Nederduitsch Hervormde Kerk van Afrika (NHKA), 1904, Algemene Kerkvergadering 1904, Kerkwet, 1904, Kerkargief, Pretoria.

Nederduitsch Hervormde Kerk van Afrika (NHKA), 1937, Algemene Kerkvergadering 1937, Kerkwet, Wallachs, Pretoria.

Nederduitsch Hervormde Kerk van Afrika (NHKA), 1957, Algemene Kerkvergadering 1957, Kerkwet, NHW-pers, Pretoria.

Nederduitsch Hervormde Kerk van Afrika (NHKA), 1985, Kerk en wêreld 2000, Kital, Pretoria.

Nederduitsch Hervormde Kerk van Afrika (NHKA), 1990, Herderlike skrywe van die Kommissie van die Algemene Kerkvergadering, Kerk en politiek, Kital, Pretoria.

Nederduitsch Hervormde Kerk van Afrika (NHKA), 1992, Algemene Kerkvergadering 1992, Kerkwet1993, Gutenberg, Pretoria.

Nederduitsch Hervormde Kerk van Afrika (NHKA), 1997, Algemene Kerkvergadering 1997, Kerkorde1997, Gutenberg, Pretoria.

Nederduitsch Hervormde Kerk van Afrika (NHKA), 2001, Notule van die 66e Algemene Kerkvergadering, Kerkargief, Pretoria.

Nederduitsch Hervormde Kerk van Afrika (NHKA), 2010, Algemene Kerkvergadering 2010, Kerkorde, Kerkargief, Pretoria.

Nederduitsch Hervormde Kerk van Afrika (NHKA), 2012, Algemene Kerkvergadering 2010, So glo ons, Sentik, Pretoria.

Nederduitsch Hervormde Kerk van Afrika (NHKA), 2013, Besluitebundel van die 70ste Algemene Kerkvergadering, Kerkargief, Pretoria.

Nederduitsch Hervormde Kerk van Afrika (NHKA), 2016a, Agenda van die 71ste Algemene Kerkvergadering, Kerkargief, Pretoria.

Nederduitsch Hervormde Kerk van Afrika (NHKA), 2016b, Algemene Kerkvergadering 2016, Notule, Kerkargief, Pretoria.

Nederduitsch Hervormde Kerk van Afrika (NHKA), 2016c, Algemene Kerkvergadering 2016, Kerkorde, Kerkargief, Pretoria.

Nederlandse Hervormde Kerk (NHK), 1969, Kerkorde, Boekencentrum, 's-Gravenhage.

Newbigin, L., 1995, The open secret: Anintroduction to the Theology of Mission, Kindle Edition, Eerdmans, Michigan.

Noordmans, O., 1984, Verzamelde werken, Deel 5, Kok, Kampen.

Oberholzer, J.P., 1993, 'Die teologiese eie-aardigheid van die Nederduitsch Hervormde Kerk: Vrae en nuanses', HTS 49(4), 870-886.

Oberholzer, J.P., 1999,'Terug op die pad', in D.J.C. Van Wyk (snr.) (red.), 20ste eeu Hervormde Teologie, pp. 449-461, Sentik, Pretoria.

Oberholzer, J.P., [2010], J P Oberholzer, ongepubliseerde reaksie op die kerkskeuring.

Pannenberg, W., 1998, Systematictheology, vol. 3, Eerdmans, Grand Rapids, Michigan.

Pelser, G.M.M., 1995, 'Die kerk in die Nuwe Testament', HTS Teologiese Studies/ Theological Studies 51(3), 645-676. https://doi.org/10.4102/hts.v51i3.1421

Petersen, C.M., 2013, Who is the church? An ecclesiology for the twenty-first Century, Fortress, Minneapolis.

Pont, A.D., [1969], 'Kerk en volk', HTS 25(3 \& 4), 202-218.

Pont, A.D., 1981, Die historiese agtergronde van ons kerklike reg, Deel 1, HAUM, Pretoria.
Pont, A.D., 2011, 'Die afwys van beswaar oor Besluit-54', Koers, 91, 3-10.

Protestantse Kerk in Nederland (PKN), Generale Synode, 2003, Kerkorde en ordinanties 2004, Boekencentrum, Zoetermeer.

Storm, J.M.G., 1989, Die Voortrekkerkerk 1836-1853, Kital, Pretoria.

Van Aarde, A.G., De Villiers, Pieter G.R. \& Buitendag, Johan, 2014, 'The forgotten struggle of Albert Geyser against racism and apartheid', HTS Teologiese Studies/ Theological Studies 70(1), Art. \#2820, 1-10. https://doi.org/10.4102/hts. v70i1.2820

Van de Beek, A., 1992, 'Vervlogen hoop en een nieuwe start', in T. Klein (red.), Veertig jaar orde in de Hervormde Kerk, Boekencentrum, Zoetermeer.

Van de Beek, A., 2012, Lichaam en Geest van Christus, Meinema, Zoetermeer.

Van den Brink, G. \& Van der Kooi, C., 2012, Christelijke dogmatiek, Boekencentrum, Zoetermeer.

Van den Heuvel, P., (red.), 2004, De toelichting op de Kerkorde van de Protestantse Kerk in Nederland, Boekencentrum, Zoetermeer.

Van der Linde, G.P.L., 1965, Die grondbeginsels van die presbiteriale kerkregeringstelsel, Pro Rege, Potchefstroom.

Van der Walt, J.J., 1976, Christus as Hoof van die Kerk en die presbiteriale kerkregering, Pro Rege, Potchefstroom.

Van Eck, E., 1995, 'J H J A Greyvenstein en A S Geyser se teologiese denke oor die volkskerkgedagte', HTS 51(3), 825-850.

Van Ruler, A.A., 1952, Bijzonder en algemeen ambt, Callenbach, Nijkerk.

Van 't Spijker, W., 1972, Goddelijk recht en kerkelijke orde bij Martin Bucer, Apeldoornse Studies, Kok, Kampen.

Van 't Spijker, W., 1990, 'Het presbyteriale-synodale stelsel', in W. Van 't Spijker et al. (red.), De kerk, pp. 326-338, De Groot Goudriaan, Kampen.

Van Wyk, D.J.C. (red.), 1978, Stemme uit die verlede, HAUM, Pretoria.

Van Wyk, D.J.C., 1985, Artikel III van die Kerkwet van die Nederduitsch Hervormde Kerk van Afrika, 'n verantwoording, Kital, Pretoria.

Van Wyk, D.J.C., 1992, 'Prof Dr A D Pont: 'n Waardering van sy lewe en werk', HTS 48(3 \& 4), 515-574.

Van Wyk, B.J., 1991, Die presbiteriaal-sinodale kerkbegrip, Kital, Pretoria.

Van Wyk, I.W.C., 1999, 'Wat glo ons van die kerk?', in D.J.C. Van Wyk (snr.) (red.), 20ste eeu Hervormde Teologie, pp. 270-299, Sentik, Pretoria.

Van Wyk, I.W.C., 2013, 'Die Hervormde Kerk: Soekend na 'n weg tussen ekklesiologiese verstarring en innovasie sonder tradisie', HTS Teologiese Studies/Theological Studies 69(1), Art. \#1999, 1-11. https://doi.org/10.4102/hts.v69i1.1999

Van Zyl, F.J., 1989, 'Volkskerk en vrye kerk', in S.J. Botha (red), Belydende volkskerk, Kital, Pretoria, 86-89.

Weber, O., 1962, Grundlagen der Dogmatik, zweiter band, Neukirchen, Moers.

Woelderink, J.G., 1951, 'De volkskerk', in Kerk en Theologie, 2de Jrg., pp. 166-173, Veenmen \& Zonen, Wageningen.

Wolff, E., 2006, 'Anatomie van 'n Teologiese Ideologie: Die Hervormde Kerk se steun aan die Apartheid Ideologie', Historia 51(1), 141-162. 